Turkish Online Journal of Qualitative Inquiry (TOJQI)

Volume 9, Issue 4, October 2018: 389-411

DOI: $10.17569 /$ tojqi.423738

Research Article

\title{
Use of Educational Movies in Classroom Management Courses: A Metaphorical Study
}

\author{
Sezen Tofur ${ }^{1}$
}

\begin{abstract}
The purpose of this present study is to determine the metaphorical perceptions of science preservice teachers on teaching classroom management courses through the educational movies. The method of research is qualitative. Phenomenological design was conducted. The study group of the research consists of 75 science preservice teacher taking the classroom management course during the fall semester of 2017 - 2018 academic year. The data were obtained through the metaphors of the preservice teachers teaching the classroom management courses through the movies declared by the Ministry of National Education in September 2017 seminar period. The preservice teachers were asked to fill in the sentence "Educational movies are like ... for classroom management courses because...". Data were analyzed through the inductive content analysis. Accordingly, 57 metaphors were grouped under 8 categories. These categories are place for learning and knowledge acquisition, guiding for situations not yet encountered, complementary for classroom management course, tool for presenting life experience, supportive for education, reflection of theoretical knowledge, preparation tool for the profession, a tool for being model. As a result, it can be mentioned that teaching classroom management courses through educational movies is positively reflected on the preservice teachers. It is thought that the study may contribute to the literature in the context of questioning the philosophical and theoretical foundations of the educational movies for classroom management and create a reference point for consecutive studies.
\end{abstract}

Keywords: Classroom management, educational movies, teacher candidates, learning environments.

\footnotetext{
${ }^{1}$ Asst.Prof.Dr., Manisa Celal Bayar University, Demirci Faculty of Education, Department of Educational Sciences, sezentofur@gmail.com, https://orcid.org/0000-0001-6518-9156
}

Received: 15.05.2018 Accepted: 29.10.2018 


\title{
Sınıf Yönetimi Derslerinde Eğitim Konulu Filmlerin Kullanılması: Metaforik Bir Çalışma
}

\begin{abstract}
$\ddot{\mathbf{O} z}$
$\mathrm{Bu}$ araştırmanın amacı, fen bilgisi öğretmen adaylarının sınıf yönetimi derslerinin eğitim konulu filmler ile işlenmesine dair metaforik algılarını belirlemektir. Araştırmanın yöntemi niteldir. Fenomenolojik desen kullanılmıştır. Araştırmanın çalışma grubunu 2017 - 2018 eğitim öğretim yılı güz döneminde sınıf yönetimi dersini almış 75 Fen Bilgisi öğretmen adayı oluşturmaktadır. Veriler sınıf yönetimi derslerini Millı̂ Eğitim Bakanlığı'nın 2017 Eylül seminer döneminde öğretmenlerin izlemesi üzere ilan edilmiş filmler üzerinden işleyen öğretmen adaylarından metaforlar yolu ile elde edilmiştir. Adaylardan "Eğitim konulu filmler sınıf yönetimi dersleri için ... gibidir; çünkü ..." cümlesini tamamlamaları istenmiştir. Veriler tümevarımcı içerik analizi ile analiz edilmiştir. Buna göre elde edilen 57 metafor 8 kategoride toplanmıştır. Bu kategoriler; öğrenme ve bilgi edinme yeri, henüz karşılaşılmayan durumlar için yol gösterici, sınıf yönetimi dersi için tamamlayıcı, yaşam tecrübesi sunma aracı, eğitim öğretimi destekleyici, teorik bilginin yansıması, mesleğe hazırlık aracı, model olma aracı şeklindedir. Sonuç olarak; sınıf yönetimi derslerinin eğitim konulu filmler yolu ile işlenmesi öğretmen adaylarına olumlu yönde yansıdığı söylenebilir. Çalışmanın sınıf yönetimi için eğitim konulu filmlerin felsefi ve teorik temellerinin sorgulanması bağlamında alan yazına katkı sağlayabileceği ve ardıl çalışmalar için bir referans noktası oluşturabileceği düşünülmektedir.
\end{abstract}

Anahtar Sözcükler: Sinıf yönetimi, eğitim konulu filmler, ögretmen adayları, ögrenme ortamları. 


\section{Introduction}

Audiovisual resources have an undeniable effect on the experiences of teenagers that constitute the cognitive domain (Fisch et al, 1997). Movies are audiovisual sources of information that can directly affect the perception and understanding (Arroio, 2010). Our desires, beliefs, and perceptions can be affected by the movies (Kavan \& Burne, 2009). In this regard, as a media element, the movies are powerful instructional environments (English \& Steffy, 1997). Cultural works that are structured by forming our understanding of organizational and social life can be seen as recreational activities in which the reality is reflected (Huczynski \& Buchanan, 2004). A subject or a message aimed be expressed through the movies can be effectively conveyed in an audiovisual way (Demirtaş, 2011). Nowadays, the rapid growth of the cinema sector has increased the importance of the use of cinema as a tool in the transfer of knowledge and in education. Very complex and comprehensive issues can be delivered to the masses through cinema. Movies serve as a tool for the transmission of all kinds of scientific and behavioral information (Birkök, 2008). Movies can be used as a tool in education, or education can be processed in scenarios within the scope of a purpose (Yurdigül, 2014). There are educational Turkish or foreign movies in whose scenarios teacher, student, school, classroom, and education are processed. Hababam Sınıfı (E. Eğilmez, 1975), Vurun Kahpeye (Ö. L. Akad, 1949), and Dead Poets Society (P. Weir, 1989) are some examples for this kind of movies.

Educational movies are the movies in which educators, educational settings, or educational stakeholders are involved. They have an informative quality by examining the problems related to education (Oruç \& Sarıbudak, 2015). Educational movies affect the attitudes of preservice teachers towards the profession (Kaşyaka, Ünlü, Akar, \& Özturan-Sağırl1, 2011; Kontaş, 2016). Through movies, preservice teachers can explore the school environment, the classroom setting, and the communication networks in the school by analyzing (Tofur 2018b). They can develop and understand real-life experiences related to the lives of the students in the light of different concepts and theories (Fennell, 2013). Indeed, movies offer real-life experiences to their followers (Kavan \& Burne, 2009).

In his study, Nevil (2012) evaluated the views of teachers about the use of movies in social studies courses. The results obtained are that the movies can be used effectively in social studies courses on the condition that the teachers are well prepared and that the necessary steps are 
taken to ensure the participation of the students in the class. Teachers also agree that students enjoy watching movies. The reason for this is that students do not have to study while watching movies, that movies change the routine monotony in the classroom and that they attract attention of the students.

When the literature is examined, it is understood that there are studies on the educational movies (Altan, 2016; Girgin, 2017; Tofur 2017; Tofur, 2018a; Tofur, 2018b; Tofur, 2018c; Silman, 2017). These studies suggest that educational movies can be used in the education of preservice teachers. However, there are no studies on the possible results of the use of educational movies in the courses. In this study conducted in this context, the educational movies are tried to be evaluated by the data collected from the students taking their classroom management courses through the educational movies. What is explored in this study is important in terms of determining how the educational movies are interpreted for classroom management courses. In addition, it is important for the preservice teachers to use the educational movies as a teaching and learning tool in the classroom management, in other courses, or in the courses they will lecture in their future teaching period. It is thought that the study may contribute to the literature in the context of questioning the philosophical and theoretical foundations of the educational movies for classroom management and create a reference point for consecutive studies. It can be said that the findings obtained from the research can serve as a theoretical ground for scale development studies which can be generated for the use of the educational movies in the classroom management courses. When the literature is examined, whereas the metaphor analyzes have been performed for the interpretation of many concepts, there has been no metaphor study on the educational movies. In this study, how preservice teachers interpret their classroom management courses taken through the educational movies is tried to be determined through metaphors.

\section{Purpose of the Research}

The purpose of this study is to determine the metaphorical perceptions of science preservice teachers on teaching classroom management courses through the educational movies. By presenting what the educational movies mean in the context of the classroom management course, the reader was enabled to carry out a general evaluation of the use of these movies as an instructional tool in classroom management courses. This study is important in terms of 
presenting the educational movies to the field staff and practitioners as a new instructional tool which can be used in classroom management courses.

In September 2017, the Ministry of National Education (MONE) published an article with a sample list related to the educational movies for teachers to watch during the seminars (MEB, 2017). In this article, with the emphasis on personal development and contribution to professional development, the teachers were asked to evaluate the movies with a critical point of view. In this study, the data were obtained from the preservice teachers who took the classroom management courses through these movies. The results of the study show how preservice teachers interpreted the movies announced by the Ministry of Education for classroom management courses.

The questions to be searched for within the scope of the purpose of the research:

1. What are the metaphors that teacher candidates mention about "the educational movies for classroom management courses"?

2. Under what categories can the metaphors obtained from the participants be grouped according to their common characteristics?

\section{Method}

In the study, the metaphors of pre-service teachers on the educational movies were examined. For this purpose, the phenomenological design of qualitative research methods was used. In the phenomenological method, the experiences of a person related to a phenomenon or concept are combined around a common meaning (Creswell, 2013). Phenomenology is a qualitative research method in which the researcher attempts to explain how one or more participants experience a phenomenon (event, situation, concept, etc.) (Christensen, Johnson \& Turner, 2015). In this study, phenomenological design was preferred since classroom management was aimed to be examined by the data obtained from the preservice teachers who took their course through the educational movies.

\section{Study Group}


The study group of this research consists of 75 science preservice teachers (43 female, 32 male) studying in Manisa Celal Bayar University, Faculty of Education in 2017-2018 Academic Year Fall Semester. Criterion sampling was conducted in the selection of the study group. In this sampling selection, the researcher chooses the sample according to pre-determined criteria (Neuman, 2010). In this study, the main criterion is that classroom management courses are taught through the educational movies. The reason why the participants were selected from the final year science teachers was that this group used the educational movies as an instructional tool in Classroom Management courses. The movies that were watched were the movies chosen from the sample movie list announced in September 2017 by MONE for the teachers to watch during their seminars. There are 30 movies in the list. In the process of selection, watching and interpretation of movies: (i) The scenarios of each movie included in the list were examined in a classroom setting. (ii) 13 movies, which are thought to be exemplary for the classroom management course in their scenarios including teachers, students, and classroom environments were chosen selected (Table 1). (iii) The related choices were made with the instructors of the course and the students. (iv) The interest and wishes of the students were taken into consideration in which movies to watch. (v) The students were divided into groups, and each group was given a movie to perform its examination and to determine the related scenes. (vi) The relevant scenes of all the chosen movies were watched with the help of smart board or projection with all the students in the classroom environment, and they were interpreted in terms of classroom management.

Table 1

Educational movies examined within the scope of classroom management course

\begin{tabular}{|c|c|c|c|}
\hline & Movies & & \\
\hline 1. & 3 Idiot (R. Hirani, 2009) & 8. & Freedom Writers (R. LaGravenese, 2007) \\
\hline 2. & The first grader (J. Chadwick, 2010) & 9. & Mr. Holland's Opus (S. Herek, 1995) \\
\hline 3. & Monsieur Lazhar (P. Falardeau, 2011) & 10. & Half Nelson (R. Fleck, 2006) \\
\hline 4. & $\begin{array}{l}\text { Hababam Sınıfı Sınıfta Kaldı (E. Eğilmez, } \\
\text { 1976) }\end{array}$ & 11. & Taare Zameen Par (A. Khan, \& A. Gupte, 2007) \\
\hline 5. & $\begin{array}{l}\text { İki Dil Bir Bavul (Ö. Doğan, \& O. Eskiköy, } \\
\text { 2009) }\end{array}$ & 12. & The Class / Entre Les Murs (L. Cantet, 2008) \\
\hline 6. & Black (S. L. Bhansali, 2005) & 13. & Les Choristes (Barratier, 2004) \\
\hline 7. & Dead Poets Society (P. Weir, 1989) & & \\
\hline
\end{tabular}

\section{Data Collection}


Data were qualitatively collected through the metaphors. The reason for collecting the data through the metaphors is to reveal the interpretation of the study group on the use of educational movies in classroom management courses. For this purpose, (i) the study group was asked to fill in the sentence "Educational movies are like ... for classroom management courses because...". (ii) 15 minutes were given to preservice teachers to complete the sentence. (iii) An explanation of what the metaphor means was provided before implementation. (iv) It has been explained that the metaphors can be defined through living or non-living concepts, events, and phenomenon.

\section{Data Analysis}

A four-stage inductive content analysis was applied to analyze the data. Inductive analysis is necessary in case of the absence of a theory related to the phenomenon examined (Strauss \& Corbin, 1990). Inductive analysis is encoding analysis based content analysis. In this way, the underlying codes and the relationships between these codes can be revealed. Data can be analyzed in four ways in qualitative research (Yıldırım \& Şimşek, 2008): (i) Data coding: This is the first stage of content analysis. At this stage, the codes were generated based on the data. Each metaphor specified by the participants was taken as a code. Initially, the metaphors were entered into Excel file in computer environment. Metaphors were ordered in alphabetical order. The codes were converted into data and checked again and again. 4 participants who did not describe any metaphors or were unclear were not included in the study. As a result, 57 codes were obtained from 71 preservice teachers. (ii) Creation of themes: Participants, researchers, and literature can be utilized to create themes. In this study, the themes were formed in accordance with the researcher and the literature. The codes were grouped according to similarities and differences of each other, and the themes were obtained. While creating the themes, it has been paid attention to create a meaningful integrity. (iii) Arrangement of codes and themes: The compatibility of the themes with the codes was revised again and again, and 8 themes were obtained. Two experts in the field of Educational Sciences were consulted during the controls. (iv) Interpretation of the findings: It is important for the researcher to obtain firsthand experience in the interpretation of the findings. In this study, the researcher is the instructor of the related course of the preservice teachers taking the classroom management course. In this sense, the findings were interpreted through the opinions supported by the first hand data obtained in the study. 


\section{Validity and Reliability of Research}

Validity is the accuracy of research. Internal validity means that there are no errors in the design of the research process (Neuman, 2010). Internal validity in qualitative research is related to the credibility of the research (Yıldırım \& Şimşek, 2008). In order to increase the credibility in the study, long-term interaction, variation, expert examination, participant confirmation methods were applied. The researcher tried to reduce the effect of subjective perceptions by long-term interaction with data sources. That the researcher is the lecturer of classroom management course of the individuals from whom the data were collected facilitated long-term interaction with the participants. The researcher observed the participants during the course of their classroom management courses in which the educational movies were used for about 6 weeks. During the observations, it was noted that whether the scenes of the educational movies were interpreted in accordance with the classroom management content or not. This situation allowed the researcher to make an objective evaluation in the interpretation of the research and its results. In the research, the data obtained from the form desired to be filled from the participants were supported by the observations made during the courses learned, and the results obtained were confirmed. In the study, an evaluation meeting was held with an expert in the field of Educational Administration. The data and results of the research were shared with the participants, and their opinions about the accuracy were obtained. The external validity of the study is related to the generalization of the results from a certain environment and a small group to the large environments and people (Neuman, 2010). As qualitative researches cannot be directly generalized to similar environments, the transmissibility concept is adopted. The external validity of qualitative research is related to the transmissibility of the obtained results to similar environments (Yıldırım \& Şimşek, 2008). For this purpose, detailed descriptive method was applied in the research. The environment in which the data was obtained was explained, and the reader was given an opportunity to animate his / her own study in his / her mind. In addition, while the data obtained from the participants were presented, descriptions were made through direct quotations, and the opportunity to obtain their own comments and results was provided to the readers.

Internal reliability in qualitative research is the consistency of the research (Yıldırım \& Şimşek, 2008). For this purpose, the method of consistency analysis is considered. The path of the researcher throughout the research, the data collection, and the analysis of the data are presented 
to the reader in detail. External reliability in qualitative research is the confirmation of research. It is expected that the researcher will be able to confirm the results obtained continuously and provide a logical explanation to the reader (Yıldırım \& Şimşek, 2008). For this purpose, a confirmation examination was carried out. The compliance of the conclusions, comments, and recommendations reached with the raw data was evaluated with the help of an Educational Administration expert.

\section{Findings}

In this study, 57 metaphors were obtained from 71 participants about the educational movies for classroom management courses. The metaphors were grouped under 8 categories. Categories, metaphors, and frequencies are presented in Table 2.

\section{Table 2}

Metaphors and categories obtained related to the educational movies in classroom management courses

\begin{tabular}{|c|c|c|c|}
\hline & Categories & Metaphors $(n=57)$ & $\begin{array}{l}\text { Frequency } \\
\text { (f) }\end{array}$ \\
\hline 1. & $\begin{array}{l}\text { Place for learning } \\
\text { and knowledge } \\
\text { acquisition }\end{array}$ & $\begin{array}{l}\text { mother }(n=1) \text {, map }(n=1) \text {, mirror }(n=1) \text {, example }(n=1) \text {, way }(n=1) \text {, } \\
\text { alternative }(n=1) \text {, source }(n=1) \text {, sweetener }(n=1) \text {, book }(n=1) \text {, the } \\
\text { moral }(n=1) \text {, tool }(n=1) \text {, informative }(n=1) \text {, star }(n=1) \text {, bridge }(n=1) \text {, , light }(n=1) \text {, } \\
\text { plane tree }(n=1) \text {, foundation of the house }(n=1) \text {, missing jigsaw } \\
\text { preliminary preparation }(n=1) \text {, irreplaceable }(n=1) \text {, me }(n=1) \text {, breath }(n=1) \\
\text { piece }(n=1) \text { reflection of the course }(n=1) \text {, }\end{array}$ & 22 \\
\hline 2. & $\begin{array}{l}\text { Guiding for } \\
\text { situations not yet } \\
\text { encountered }\end{array}$ & $\begin{array}{l}\text { mother }(n=1) \text {, compass }(n=1) \text {, map }(n=4) \text {, traffic police }(n=1) \text {, , } \\
\text { guide }(n=1) \text {, polar star }(n=1) \text {, user guide }(n=1) \text {, guide map }(n=1) \text {, } \\
\text { navigation }(n=1) \text {, signboard }(n=1) \text {, lantern }(n=1) \text {, sun }(n=2) \text {, } \\
\text { example }(n=1) \text { experience }(n=1) \text {, whole }(n=1) \text {, rehearsal }(n=1) \text {, } \\
\text { informative }(n=1)\end{array}$ & 21 \\
\hline 3. & $\begin{array}{l}\text { Complementary for } \\
\text { classroom } \\
\text { management course }\end{array}$ & $\begin{array}{l}\text { suitable }(n=1) \text {, map }(n=1) \text {, example }(n=1) \text {, sweetener }(n=1) \text {, course } \\
\text { equipment }(n=1) \text {, appetizer }(n=1) \text {, skeleton system }(n=1) \text {, sun } \\
(n=1) \text {, supplementary source }(n=1) \text {, bone }(n=1) \text {, love }(n=1) \text {, house } \\
\text { columns }(n=1) \text {, backbone }(n=1) \text {, seed of the fruit }(n=1) \text {, puzzle } \\
(n=1) \text {, family }(n=1) \text {, reflection of course }(n=1)\end{array}$ & 17 \\
\hline 4. & $\begin{array}{l}\text { Tool for presenting } \\
\text { life experience }\end{array}$ & $\begin{array}{l}\text { epitomist }(n=1) \text {, way }(n=1) \text {, guide }(n=2) \text {, mirror }(n=1) \text {, precedent } \\
(n=1) \text {, map }(n=1) \text {, example }(n=1) \text {, mirror }(n=1) \text {, essential }(n=1)\end{array}$ & 10 \\
\hline
\end{tabular}




\begin{tabular}{|c|c|c|c|}
\hline & Categories & Metaphors $(\mathrm{n}=57)$ & Frequency \\
\hline 5. & $\begin{array}{l}\text { Supportive for } \\
\text { education }\end{array}$ & $\begin{array}{l}\text { reinforcer }(n=1) \text {, course equipment }(n=1) \text {, important }(n=1) \text {, star } \\
(n=1) \text {, bridge }(n=1) \text {, tree }(n=1) \text {, essential }(n=1) \text {, house columns } \\
(n=1) \text {, supplementary source }(n=1) \text {, sweetener }(n=1)\end{array}$ & 10 \\
\hline 6. & $\begin{array}{l}\text { Reflection } \\
\text { theoretical } \\
\text { knowledge }\end{array}$ & $\begin{array}{l}\text { suitable }(n=1) \text {, example }(n=1) \text {, map }(n=1) \text {, book }(n=1) \text {, reflection of } \\
\text { course }(n=1) \text {, mirror }(n=1)\end{array}$ & 6 \\
\hline 7. & $\begin{array}{l}\text { Preparation tool for } \\
\text { the profession }\end{array}$ & $\begin{array}{l}\text { preliminary preparation }(n=1) \text {, fore step }(n=1) \text {, tree root }(n=1) \text {, } \\
\text { fragment }(n=1) \text {, tool }(n=1)\end{array}$ & 5 \\
\hline \multirow[t]{2}{*}{8.} & $\begin{array}{l}\text { A tool for being } \\
\text { model }\end{array}$ & a model $(\mathrm{n}=1)$, amusement park $(\mathrm{n}=1)$ & 2 \\
\hline & Total & & 91 \\
\hline
\end{tabular}

The metaphors most frequently repeated by the participants are the metaphors of mirror, map, and example with 4 of them. Metaphors are grouped under categories according to the metaphor explanations of the participants. The same metaphor can be specified under more than one category according to its explanations. By taking place in 4 different categories, the map metaphor is the code belonging to the most categories.

\section{Educational Movies as Place for Learning and Knowledge Acquisition}

The metaphors gathered under this category were grouped in accordance with that the educational movies are seen as the place of learning and knowledge acquisition in terms of classroom management course by the preservice teachers. 22 metaphors were obtained from 22 participants. The metaphors obtained are arrayed as mother $(n=1)$, map $(n=1)$, mirror $(n=1)$, example $(n=1)$, way $(n=1)$, alternative $(n=1)$, source $(n=1)$, sweetener $(n=1)$, book $(n=1)$, the moral $(n=1)$, tool $(n=1)$, informative $(n=1)$, star $(n=1)$, bridge $(n=1)$, plane tree $(n=1)$, foundation of the house $(n=1)$, light $(n=1)$, preliminary preparation $(n=1)$, irreplaceable $(n=1)$, missing jigsaw piece $(n=1)$, reflection of the course $(n=1)$, breath $(n=1)$. Only one metaphor was produced from each metaphor. The participants interpreted the educational movies with regard to learning and knowledge for the metaphors grouped under this title. The explanations of some of the metaphors grouped are as follows: The moral: “...It takes lessons for us.” [K46]. Book: “...There are a lot of information and cases we need to catch. Watching movies is the same as reading books.” [K4]. Missing jigsaw piece: “...It shows what is missing in education or classroom management." [K5]. Reflection of course: “...We can see everything we can 
encounter during our education.” [K21]. Breath: “...It shows the precautions we will take against the problems we may face in everyday life." [K27].

\section{Educational Movies as Guiding for Situations not yet Encountered}

The metaphors gathered under this category were generated in the context of guiding for situation not yet countered for the preservice teachers. 17 metaphors were obtained from 21 participants. The metaphors obtained under this category are arrayed as the metaphors of mother $(n=1)$, compass $(n=1)$, map $(n=4)$, traffic police $(n=1)$, guide $(n=1)$, polar $\operatorname{star}(n=1)$, user guide $(n=1)$, guide map $(n=1)$, navigation $(n=1)$, signboard $(n=1)$, lantern $(n=1)$, sun $(n=2)$, example $(n=1)$ experience $(n=1)$, whole $(n=1)$, rehearsal $(n=1)$, informative $(n=1)$. Participants perceived the movies for the classroom management courses as a guide on how to act as a teacher and how to behave in relation to the problems they would face in the profession. The explanations of some of the metaphors grouped are as follows: Compass: “... shows us the direction. He tells us how to be a teacher or not." [K24]. User guide: “... shows how to apply the techniques we learned.” [K69]. Map: “...When we do not sometimes know what to do, we can get help from the movies." [K43]. Map: “... shows alternative multiple routes for many different situations." [K62]. Experience: “...As we watch the movies, by taking the sections from there, we make inferences about that I can do so, or that I would not be right because of the reactions by the students.” [K40]. Mother: “...shows us our mistakes and what we need to do.” [K6]. Rehearsal: “...addresses problems and guides you on how to deal with these problems.” [K20].

\section{Educational Movies as Complementary for Classroom Management Course}

The metaphors gathered under this category explained the educational movies as complementary for the education in classroom management courses. 17 metaphors were obtained from 17 participants. Only one metaphor was produced from each metaphor. Only one metaphor was produced from each metaphor. The metaphors obtained are arrayed as suitable $(n=1)$, map $(n=1)$, example $(n=1)$, sweetener $(n=1)$, course equipment $(n=1)$, appetizer $(n=1)$, skeleton system $(n=1)$, sun $(n=1)$, supplementary source $(n=1)$, bone $(n=1)$, love $(n=1)$, house columns $(n=1)$, backbone $(n=1)$, seed of the fruit $(n=1)$, puzzle $(n=1)$, family $(n=1)$, reflection of course $(n=1)$. Metaphors gathered under this title interpreted the educational movies as complementary factor for classroom management courses and as an element facilitating learning and teaching in classroom management. The explanations of some of the metaphors 
grouped are as follows: Sweetener: “...Classroom management courses can be taught, even if not movies. However, there is difficulty in both learning and teaching, and the course is monotonous and boring. Movies give it taste. It is learned as well as a delicious meal, and the percentage of remembering increases." [K12]. Appetizer: “...is complementary to the education courses we have studied.” [K67]. Bone: “...Keeps the structure standing and ensures permanence, durability, and efficiency.” [K25]. Love: “...is like two lovers, one without the other is missing." [K17]. House columns: “...is necessary to ensure the permanence of the subjects described in the classroom management course and to correctly perceive the information. Educational movies are the building blocks of classroom management." [K13]. Family: “...They will be stronger when they all come together. They will be weaker when they breaks. They support each other like family." [K70].

\section{Educational Movies as Tool for Presenting Life Experience}

The metaphors gathered under this category explained the educational movies as tools presenting life experience related to the teaching profession. 9 metaphors were produced from 10 participants. The metaphors obtained are the metaphors of epitomist $(n=1)$, way $(n=1)$, guide $(n=2)$, mirror $(n=1)$, precedent $(n=1)$, map $(n=1)$, example $(n=1)$, mirror $(n=1)$, essential $(n=1)$. Only one metaphor was produced from each metaphor apart from guide metaphor for which 2 metaphors were generated. The metaphors collected under this title have described the educational movies as providing examples of the situations that preservice teachers might encounter in their professional lives and providing experience without experience. It is also emphasized that they are guiding because of providing life experience. The explanations for the metaphors under this category are as follows: Way: “...These movies are an experience for preservice teachers. We watch the events in these movies, and see how we should act in such events.” [K16]. Guide: “...reflects the situations we will encounter in real life.” [K1]. Guide: “...is guiding and provides experience without experience." [K72]. Mirror: “...was a reflection of the probable issues and the student-teacher, teacher-teacher, teacher-parents situations.” [K41]. Mirror: “...reflected on us how to behave in a classroom setting." [K49]. Precedent: "...When we became teachers, we saw what we would do in case of a situation." [K35]. Essential: “...creates a concrete scheme for teachers.” [K39]. Epitomist: “...reflects the experiences experienced before. It shows us what to do in the face of them." [K73]. Map: 
“...is a guide. The map is experience. No matter how much you know, experience always leads." [K33].

\section{Educational Movies as Supportive for Education}

The metaphors gathered under this category explained the educational movies as supportive for education in classroom management courses. 10 metaphors were obtained from 10 participants. Only one metaphor was produced from each metaphor. These metaphors are reinforcer $(n=1)$, course equipment $(n=1)$, important $(n=1), \operatorname{star}(n=1)$, bridge $(n=1)$, tree $(n=1)$, essential $(n=1)$, house columns $(n=1)$, supplementary source $(n=1)$, sweetener $(n=1)$. The metaphors grouped under this title described the educational movies as a factor that embodied the events, increased the memorability, and made the lesson more fun and a means to provide learning. The explanations of some of the metaphors grouped are as follows: Bridge: “... acts as a bridge like teachers and provides permanent learning." [K19]. Star: “...Such movies allow us to learn the lesson more fun and deeply. It enables us to examine events and situations well." [K28]. Important: “...is important because it embodies the events in the classroom management course and increases the permanence in the mind." [K11]. Reinforcer: "...Both students and teachers will be more eager and enthusiastic in the course." [K29]. Supplementary source: “... are also important in terms of meeting the needs and interests of the students in classroom management courses." [K31].

\section{Educational Movies as Reflection of Theoretical Knowledge}

The metaphors gathered under this category explained the educational movies as a reflection of the theoretical knowledge presented in classroom management courses. 6 metaphors were obtained from 6 participants. Only one metaphor was produced from each metaphor. These metaphors are listed as suitable $(n=1)$, example $(n=1)$, map $(n=1)$, book $(n=1)$, reflection of course $(n=1)$, mirror $(n=1)$. The metaphors gathered under this title described the movies on education as the revival of theoretical knowledge, the reflection of the course, and the development of theoretical knowledge. The explanations of some of these metaphors are as follows: Suitable: “... While we are looking for the theoretical subjects studied in the course in the movie, we are more internalizing the subjects." [K32]. Example: “...These movies are the revival of the theoretical knowledge shown in the course. In these movies, the effect of the subjects studied in the course on students, teachers, and etc. can be observed. It also improves 
the ability of empathy.” [K14]. Map: “...may give us more practical and real-life information, such as the revival of the subjects that we can theoretically find in literature." [K51]. Reflection of course: “...Since we did not start teaching profession in real-life, we had the chance to see what we learned theoretically." [K50]. Mirror: “...In this way, in the movie, we saw what we had learnt in the course, and we thought what we would do, so it was reflective like a mirror." [K15].

\section{Educational Movies as Preparation Tool for the Profession}

The metaphors collected under this category explained the educational movies as pre-service preparation tools for preservice teachers. 5 metaphors were obtained from 5 participants. These metaphors are listed as preliminary preparation $(n=1)$, fore step $(n=1)$, tree root $(n=1)$, fragment $(n=1)$, tool $(n=1)$. Only one metaphor was produced from each metaphor. The metaphors collected under this title characterize the educational movies as a preliminary information and preparation tool for the professional foundation of preservice teachers. The explanations of the metaphors are as follows: Preliminary preparation: “...allows us to see the situation that the movements will reveal in the student." [K53]. Fore step: “...The next steps are more predictable.” [K58]. Tree root: “...These movies will provide us with a foundation for the attitudes and behaviors that we will do when we become teachers." [K56]. Fragment: "...enables to estimate the good or bad situations that preservice teachers are expected to live in the future and to acquire some knowledge for these situations.” [K2]. Tool: “...serves as a tool providing the preliminary information and preparation before experiencing the event." [K18].

\section{Educational Movies as a Tool for Being Model}

The metaphors collected in this category are explained as a tool for being model of the role of teacher in the movies for the preservice teachers. 2 metaphors were obtained from 2 participants. Only one metaphor was produced from each metaphor. Metaphor explanations are as follows: Amusement park: “...In the places like the amusement park, people choose the toy they want to ride the most. In the movies we watch, we ourselves choose the people we take as examples according to their characteristics we like." [K66]. A model: “...We try to adapt what we see in the movies to our own lives." [K34]. 


\section{Discussion, Conclusion, and Recommendations}

In this study, which was conducted so as to determine the metaphorical perceptions of preservice teachers on the educational movies for the classroom management courses, 57 metaphors mentioned by the preservice teachers were examined under 8 categorical topics. According to this, the educational movies in the classroom management courses are respectively characterized as place for learning and knowledge acquisition, guiding for situations not yet encountered, complementary for classroom management course, tool for presenting life experience, supportive for education, reflection of theoretical knowledge, preparation tool for the profession, a tool for being model.

In the category with the most metaphors, the educational movies are stated as place for learning and knowledge acquisition. Under this title, the participants evaluated the educational movies as related to information and learning or described them as an audio-visual book. Movies are tools that provide information to the audience in each image. Movies are powerful instructional environments (English \& Steffy, 1997). A well-chosen movie on the subject will help students develop their analytical skills (Champoux, 2007). In this sense, it can be said that the right movies to be chosen in the classroom management courses will create a learning environment for the preservice teachers to reinforce their classroom management knowledge.

The second category with the most metaphors is the category of guiding for situations not yet encountered. The most produced metaphor under this category is the metaphor of map. Participants described the educational movies as a guide related to how they should be a teacher and how they should react in case of a problem. In addition, in his study, Yurdigül (2014) stated that the problems encountered in education and what the community expects from education can be transferred to the watchers through the educational movies. In their study, Oruç and Sarıbudak (2015) emphasized that the educational movies have an idea about the problems and solutions that exist in education. These findings support the guiding metaphor for the situations that have not yet been encountered in the study. In this sense, it can be said that the educational movies are guiding for the teachers in their professions. 
In the third category with the highest number of metaphors, it is stated that the educational movies are complementary to the classroom management courses. Under this category, the educational theme is defined as a factor that facilitates teaching and learning in classroom management. Classroom Management courses can be taught even if there are no educational movies. However, teaching course through the educational movies will facilitate learning of the students by supporting the content of the subject. Stability, robustness and efficiency will be provided. It can be said that preservice teachers can have a better command of the classroom management course content through the educational movies.

The categories of tool for presenting life experience and supportive for education share the fourth category where the most metaphors are gathered. The educational movies under the title of tool for presenting life experience were described as tools providing examples of the situations that preservice teachers may encounter in their professional lives. It was also emphasized that the movies play a guiding role by providing life experience to their watchers. The educational movies offer short compressed imitation of life experiences for the watchers as a good communication and interaction environment (Tofur, 2018a). It allows interaction with characters, situations and dilemmas in the movie (Tan, 2006). The preservice teachers can analyze and explore school environment, classroom environment, communication networks in schools (teacher-teacher, teacher-student, student-student, teacher-parent) through the educational movies (Tofur, 2018b). This will strengthen the reflective thinking skills of preservice teachers by enabling them to actively and continuously study the educational issues. The educational movies offer exemplary life experiences for the preservice teachers.

In the category of supportive for education, the educational movies are considered as factors that embody events, increase memorability, make the lesson more enjoyable and provide learning. As a matter of fact, we recall $10 \%$ of what we read, $20 \%$ of what we hear, $30 \%$ of what we see, $50 \%$ of what we see and hear, $70 \%$ of what we say and present, and $90 \%$ of what we do. We acquire $\% 3$ through sense of smell, \%3 through sense of taste, $\% 6$ through sense of touch, \%13 through sense of hearing, and \%75 through sense of sight (Hesapçığlu, 2008; Wiater, 1999). In this sense, it can be said that the use of educational movies that support our sense of sight and hearing at the same time has an important role in obtaining information and remembering what is learned. Interpretations and discussions that can be made after watching 
the educational movies also contribute to the recall of those learned due to the contribution of what is said.

Another category is the educational movies as reflection of theoretical knowledge. The metaphors collected under this category characterize the educational movies as the revival of theoretical knowledge, the reflection of the course, and the development of theoretical knowledge. The educational movies provide the presentation of the subjects covered in the classroom management course not only through printed materials or through verbal expression, but also as audiovisual. The educational movies provide preservice teachers with concrete images of theoretical knowledge. The concrete images that are presented provide convenience in understanding the theoretical knowledge in terms of addressing different sensory organs while providing the persistence of knowledge in terms of being the reflection of theoretical knowledge.

In the category of educational movies as preparation tool for the profession, the educational movies are considered as a preliminary information and preparation tool for the professional foundation of preservice teachers. The failure of the perceptions of the preservice teachers on the profession and the situations encountered during the practice and the failure to produce solutions to the problems encountered in this sense cause preservice teachers to encounter some kind of reality shock. MacDonald (1999) stated in his study that preservice teachers do not see themselves as sufficient when it comes to real professional practices and that they are unprepared for the problems they may encounter. In this respect, it can be said that the movies including school and teacher can be useful in order to transfer theoretical knowledge to practice and to see a similarity in the preparation of preservice teachers for professional practice (Kaşkaya, 2013). In its article published in 2017, the Ministry of National Education asked the teachers to watch the movies that were announced with their emphasis on personal development and professional development. All these findings support the view of preservice teachers about the education movies as a preparation tool for the profession.

In the last category, the educational movies are shown as a tool for being model. The attention of the society to the movies mostly results in the desire to be like the people in the movie in terms of food \& beverage or clothes of the players in the movies (Yurdigül, 2014). Through the teacher models presented in the educational movies, the preservice teachers can see different types of teacher models that may exist. Thus, they have the opportunity to question their own 
teaching. In their study, Akınc1-Yüksel (2015) reached the conclusion that the movies including the representations of school, student, and teacher were not fictional movies and that they held a mirror to society and culture. Wegner (1977) emphasized that the best teacher, the best scientist, or the best poet can be brought to the classes through the movies. All of these results support the role of the educational movies as a tool for being model for classroom management courses. In this respect, it can be said that preservice teachers can have ideas about how to be a teacher or not by means of the educational movies they watch. They will be able to question themselves about which teacher model they will be in case of the situations they may encounter. At present, thousands of movies are available for use in the classroom. In many countries, the movies prepared for such subjects as drug use, sexuality, suicide are utilized in the classrooms (Kaya, 2006). This present study supports that the educational movies can be used as a teaching and learning tool in classroom management courses.

As a result, teaching the classroom management courses through the educational movies is reflected positively to the preservice teachers. The educational movies (i) are a place for learning and acquiring knowledge in the classroom management classes for preservice teachers, (ii) provide guidance to preservice teachers for the situations they have not encountered yet, (iii) are a factor that complements the classroom management courses, (iv) develop teacherreflective thinking skills and provide them with exemplary life experiences, (v) are instructional tools which have an important share in taking information and remembering what is being learned since they can address our hearing and seeing sensations at the same time (vi) present theoretical images and provide theoretical information reflections that facilitate the clarity of knowledge, (vii) are a tool for pre-service preparation and post-service professional development for the teachers, and (viii) offer preservice teachers the opportunity to question their own teaching by presenting different teacher models.

This study including some evaluations on the use of educational movies as a teaching and learning tool in classroom management courses is limited by the fact that the study group only includes science preservice teachers. In this respect, it may be advisable for researchers to repeat the study with the preservice teachers in different fields and to discuss possible results. It can be suggested that instructors using the educational movies as instructional tools in different courses in the faculties of education may repeat the study in relation to their own courses. An elective course on educational movies can be lectured in the faculties of education by taking 
into consideration the contribution for the preservice teachers to their professional and personal development. In the study, it is thought that the categories in which the metaphors are grouped can serve as a theoretical ground in scale development studies that can be used for the use of educational movies in classroom management courses. 


\section{References}

Akıncı-Yüksel, N. A. (2015). Kültürel bir film olarak Türkiye'de sinema filmlerinde okul, öğretmen ve öğrenci temsilleri. Global Media Journal TR Edition, 6(11), 1-17.

Altan, M. Z. (2016). Öğretmenliğe dair, filmler ve ögretmenler. Ankara: Pegem Akademi.

Arroio, A. (2010). Context based learning: a role for cinema in science education. Science Education International, 21(3), 131-143.

Birkök, M. C. (2008). Bir toplumsallaştırma aracı olarak eğitimde alternatif medya kullanımı: sinema filmleri. Uluslararası İnsani Bilimler Dergisi, 5(2), 1-12.

Champoux, J. E. (1999). Film as a teaching resource. Journal of Management Inquiry, 8(2), 206-217.

Christensen, L.B., Johnson, R.B., \& Turner, L.A. (2015). Nitel ve karma yöntem araştırmaları In M. Sever (Trans.), A. Aypay, (Trans. Ed.), Araştırma yöntemleri desen ve analiz (pp. 400-433). Ankara: An1.

Creswell, J.W. (2013). Nitel araştırma yöntemleri beş yaklaşıma göre nitel araştırma ve araştırma deseni. Ankara: Siyasal Kitapevi.

Demirtaş, M. (2011). Halkla ilişkiler filmleri ve halkla ilişkiler filmlerinde öncüler: ABD ve Almanya örneği. İstanbul Aydın Üniversitesi Sosyal Bilimler Dergisi, 3(9), 34-52.

English, F.W., \& Steffy, B.E. (1997). Using film to leadership in educational administration. Educational Administration Quarterly, 33(1), 107-115.

Fennell, H.A. (2013). Reel stories of teaching: film and teacher education. Action in Teacher Education (Association of Teacher Educators), 35(5-6), 445-461. doi: 10.1080/01626620.2013.846762.

Fisch, S.M., Yotive, W., McCann, S.K., Scott, M., \& Chen, L. (1997). Science in Saturday morning: children's perceptions of science in educational and non-educational cartoons. Journal Educational Media, 23, 157-167.

Girgin, M. (2017). Ĕ̌gitim filmleri. Ankara: Vize. 
Hesapçığlu, M. (2008). Ders araçları.In Öğretim ilke ve yöntemleri (pp. 405-490). Ankara: Nobel.

Huczynski, A., \& Buchanan, D. (2004). Theory from fiction: A narrative process perspective on the pedagogic use of feature films. Journal of Management Education, 28, 702-726.

Kaşyaka, A. (2013). Okul ve Öğretmen Içerikli Sinema Filmlerinin Öğretmen Adaylarının Pedagojik Inançları ve Eleştirel Yansıtma Becerileri Üzerine Etkisi. (Yayımlanmamış Doktora Tezi), Gazi Üniversitesi Eğitim Bilimleri Enstitüsü, Ankara.

Kaşyaka, A., Ünlü, İ., Akar, M. S., \& Özturan-Sağırlı M. (2011). Okul ve öğretmen içerikli sinema filmlerinin öğretmen adaylarının mesleki tutumlarına ve özyeterlik algılarına etkisi. Kuram ve Uygulamada Ĕ̈itim Bilimleri, 11(4), 1765-1783.

Kavan, H., \& Burne, J. (2009). Using film to teach communication concepts at university. The International Journal of Learning, 16(10), 429-440.

Kaya, Z. (2006). Öğretim teknolojileri ve materyal geliştirme. Ankara: Pegem Akademi.

Kontaş, H. (2016). The effect of an education-theme movie on academic motivation of teacher candidates and their attitude towards teaching profession. Journal of Education and training studies, 4(6), 93-103

MacDonald, D. (1999). Teacher attrition: a rewiev of literatüre. Teaching and Teacher Education, 15(8), 835-848.

Millî Eğitim Bakanlığı [MEB] (2017). Öğretmenlerin 2017 Eylül Dönemi Mesleki Gelişim Çalışmaları. Retrieved May 7, 2018, from https://oygm.meb.gov.tr/meb_iys_dosyalar/2017_08/28191925_EK_Mesleki_YalYY malar_ProgramY_EylY1_2017.pdf

Neuman, W. L. (2010). Toplumsal araştırma yöntemleri nitel ve nicel yaklaşımlar (4. Baskı) (S. Özge, Çev). İstanbul: Yayın odası.

Nevil, S. A. (2012). Teachers' Perspectives on Use of Movies in the Social Studies Classroom. (Unpublished Master's Thesis). Ohio University, USA.

Oruç, Ş., \& Sarıbudak, D. (2015). Okul yöneticilerinin ve öğretmenlerin eğitim içerikli filmlerin eğitim ortamlarına etkisine ilişkin görüşleri. International Journal of Field Education, 1(1), 19-41.

Silman, F. (2017). Eğitim konulu filmler. Ankara: Pegem Akademi. 
Strauss, A., \& Corbin, J. M. (1990). Basic of qualitative research: Grounded theory procedures and techniques. Sage Publications, Inc.

Tan, C. (2006). Philosophical reflections from the silver screen; using films o promote reflection in pre-service teachers. Reflective Practice, 7(4), 483-497.

Tofur, S. (2017). 'Hababam Sınıfı' filmi ilk serisinin Katz'ın yönetsel üç beceri yaklaşımına göre incelenmesi. The Journal of Academic Social Science Studies, 56, 53-66. doi:10.9761/JASSS7048

Tofur, S. (2018a). Case of a Classroom Management Model in Cinematographic Narration: The Movie 'Stand and Deliver. International Online Journal of Educational Sciences, 10(2), 146-161. doi:10.15345/iojes.2018.02.010

Tofur, S. (2018b). Sinematografik anlatıda okuldaki iletişim ağları: Ron Clark'ın hikayesi filmi örneği. Eğitim Kuram ve Uygulama Araştırmaları Dergisi, 4(1), 54-67.

Tofur, S. (2018c). Sinematografik anlatıda Hersey-Blanchard durumsal liderlik modeli: Koro filmi. Kuramsal Ĕgitimbilim Dergisi, 11(4), 822-837. doi:10.30831/akukeg.399319

Wegner, H. (1977). Teaching with film. Indiana: Phi Delta Kappa Educational Foundation Bloomington.

Wiater, W. (1999). Von schüler her unterrichten. Eine neue didaktik für eine veränderte schule. Auer: Donaunurörth.

Yurdigül, A. (2014). Eğitim olgusunun sinematografik anlatıdaki yeri üzerine bir yaklaşım denemesi ('Bal' filmi örneği). Ekev Akademi Dergisi, 18(60), 487-502.

Yıldırım, A., \& Şimşek, H. (2008). Sosyal bilimlerde nitel araştırma yöntemleri (6. Baskı). Ankara: Seçkin.

\section{Filmography}

Akad, Ö. L. (Director), (1949). Vurun kahpeye [Motion picture]. Turkey: Erman film.

Barratier, C. (Director), (2004). Les choristes [Motion picture]. France: Vega film.

Bhansali, S. L. (Director), (2005). Black [Motion picture]. India: Applause Bhansali Productions. 
Cantet, L. (Director), (2008). The class/Entre les murs [Motion picture]. France: Haut et Court.

Chadwick, J. (Director), (2010). The first grader [Motion picture]. England: Sixth Sense Productions.

Doğan, Ö., \& Eskiköy, O. (Directors), (2008). İki dil bir bavul [Motion picture]. Turkey/Netherlands: Tiglon.

Eğilmez, E. (Director), (1975). Hababam sınıfı [Motion picture]. Turkey: Arzu Film.

Eğilmez, E. (Director), (1976). Hababam sınıfı sınıfta kaldı [Motion picture]. Turkey: Arzu film.

Falardeau, P. (Director), (2011). Monsieur Lazhar [Motion picture]. Canada: Micro_scope.

Fleck, R. (Director), (2006). Half Nelson. [Motion picture]. United States: Think film.

Herek, S. (Director), (1995). Mr. Holland's Opus [Motion picture]. United States: Hollywood Pictures.

Hirani, R. (Director), (2009). 3 Idiots [Motion picture]. India: Vinod Chopra Productions.

Khan, A., \& Gupte, A. (Directors), (2007). Taare zameen par [Motion picture]. India: Aamir Khan Productions.

LaGravense, R. (Director), (2007). Freedom writers [Motion picture]. United States: Paramount Picture.

Weir, P. (Director), (1989). Dead poets society [Motion picture]. United States: Touchstones Pictures. 